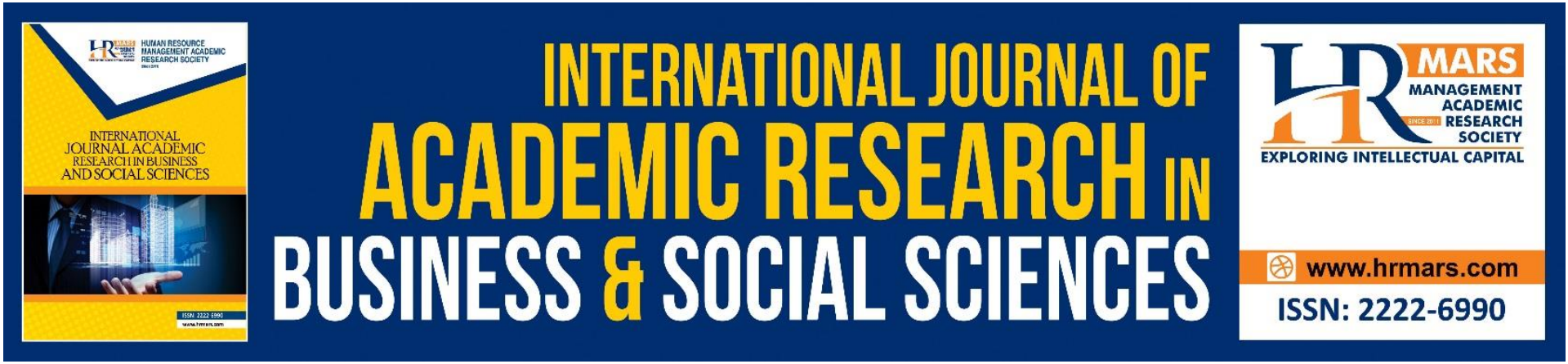

\title{
Flipped Classroom in English Language Teaching and Learning: A Systematic Literature Review
}

Hui Kiang Ngo, Melor Md Yunus

To Link this Article: http://dx.doi.org/10.6007/IJARBSS/v11-i3/8622

DOI:10.6007/IJARBSS/v11-i3/8622

Received: 15 January 2021, Revised: 16 February 2021, Accepted: 28 February 2021

Published Online: 13 March 2021

In-Text Citation: (Ngo \& Yunus, 2021)

To Cite this Article: Ngo, H. K., \& Md Yunus, M. (2021). Flipped Classroom in English Language Teaching and Learning: A Systematic Literature Review. International Journal of Academic Research in Business and Social Sciences, 11(3), 185-196.

Copyright: @ 2021 The Author(s)

Published by Human Resource Management Academic Research Society (www.hrmars.com)

This article is published under the Creative Commons Attribution (CC BY 4.0) license. Anyone may reproduce, distribute, translate and create derivative works of this article (for both commercial and non-commercial purposes), subject to full attribution to the original publication and authors. The full terms of this license may be seen

at: http://creativecommons.org/licences/by/4.0/legalcode

Vol. 11, No. 3, 2021, Pg. 185 - 196

http://hrmars.com/index.php/pages/detail/IJARBSS

JOURNAL HOMEPAGE

Full Terms \& Conditions of access and use can be found at http://hrmars.com/index.php/pages/detail/publication-ethics 


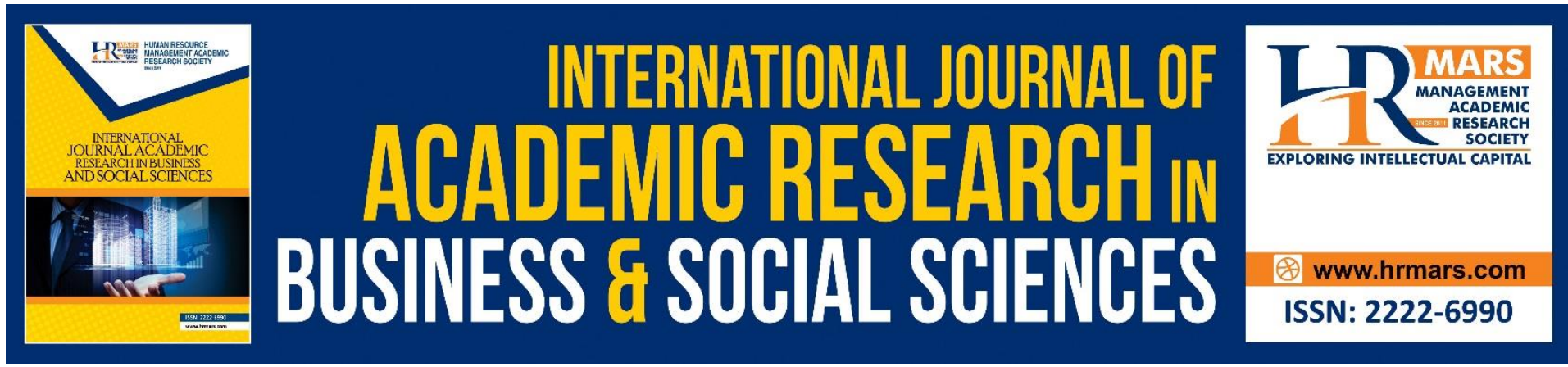

\title{
Flipped Classroom in English Language Teaching and Learning: A Systematic Literature Review
}

\author{
Hui Kiang Ngo, Melor Md Yunus \\ Universiti Kebangsaan Malaysia, Bangi, Selangor, Malaysia
}

\begin{abstract}
Flipped or inverted classroom has been a new trend in the education world. The idea of this educational practice has been widely accepted by most of the countries, and being applied in primary, secondary, and tertiary levels. The perceptions, effectiveness, and challenges of implementing flipped classroom has always been one of the popular fields of studies by researchers all over the world. The literature review shows an internationally extensive view of international studies on the perceptions of teachers and learners towards the implementation of flipped classroom, especially in the English Language teaching and learning classroom. This systematic literature review comprehensively analysed 18 articles from the year 2016 until 2020 including full-text articles from online sources for better review. The main findings of the past studies were being displayed in tables for better understanding. Findings of this review indicated that most of the English teachers and learners participated in the past studies, agreed that Flipped Classroom approach brings benefits to the English language teaching and learning practice.
\end{abstract}

Keywords: Flipped Classroom, English Language, Education, Systematic Literature Review, Perceptions

\section{Introduction}

One of the concerns that educators have in todays' classroom is the attitudes of the learners. They are unwilling to participate in the discussion, shy to give opinions and timid to try new things. These passive learners have low ability in problem-solving and they are very dependent towards the teachers, or their peers with advanced proficiency level. The traditional teaching and learning method do not allow the learners to have time in discussing their lesson. The teachers act as information providers by providing a lot of input and the learners gradually became passive learners. There is insufficient time for any discussion to take place in the traditional classroom. Farrah \& Qawasmeh (2018) stated, the dependency of learners due to the traditional teaching and learning approach requires the need of converting the old methods to modern teaching strategies. Flipped classroom is one of the modern learners-centred strategies.

Flipped Classroom approach has been receiving mass attention all over the world as it is focusing on the learner-centred learning. With Flipped Classroom approach, we hope to produce active learners among the young generation. When the learners are active, they play active role in their own learning. They are dynamic learners; they look for their new 
knowledge without depending on teachers. The theory of flipped learning is totally opposite from the traditional teaching and learning approach, as it "flipped" the traditional method. In a flipped or inverted classroom, the learners are provided with out-of-class materials where they read, study, and review them individually. Discussion, questioning session or collaboration works take place after that. This allowed the learners to know what they should be focusing on during the lesson and they may participate actively as they have the materials ready. A flipped classroom lets the learners to review the materials in their comfortable speed based on their competency level (Han, 2015). This is crucial for the learners who are slower compared to their peers. By flipping classroom, learners may do their learning at home before the teachers discuss on the topic in the classroom during the next session. The learners have time to prepare themselves for the discussion as well. This scenario helps both learners and teachers to have adequate of time in discussing the topic and have in-depth understanding on the topics discussed.

Therefore, a systematic literature studies on the implementation of Flipped Classroom approach need to be done to understand more about the targeted approach. So, a systematic literature review is being carried out to further discuss the modern learners-centred approach. The main aim of this systematic review is to present a synthesis of empirical found in the past related studies on the execution of flipped classroom in English language classroom, so that further studies and research in this area can be conducted.

\section{Research Objectives}

- To explore the English language teachers' perceptions on the implementation of flipped classroom

- To explore the learners' perceptions on the implementation of flipped classroom

\section{Research Questions}

- What are the English language teachers' perceptions on the implementation of flipped classroom?

- What are the learners' perceptions on the implementation of flipped classroom?

\section{Literature Review \\ Flipped Classroom Approach}

Flipped classroom approach is a trend in foreign countries for a long time (Du, 2018). The objective of the approach is to overcome teaching and learning challenges contributed by time and place. According to Du (2018), flipped classroom is also known as inverted classroom, it "flipped" the traditional teacher-centred teaching mode. In flipped classroom, the learners are being provided with resources from their teachers so that they could perform the process of knowledge transfer before the class. According to Carhill-Poza (2019), flipped learning allows language teachers to focus on interaction and socialization in the classroom while providing more learning opportunities outside the classroom. They may search for more information on the internet, or they may watch videos or listen to the audio prepared by the teachers. Then, when in the classroom, they can have a complete discussion on the topics as the teachers do not have to give lectures about the topic anymore. The learners have gone through the materials beforehand. This is meaningful as it allows teachers to utilise class time for the learners to have discussion with their peers, time can be managed and allowed learners to have more collaborative activities (Halili \& Zainuddin 2015; Yavuz \& Ozdemir 
2019). In class, they will have questioning and answering (Q\&A) session, group discussion, projects, problem-based learning, interactive exchanges, and other activities which are learners-centred. The questions and doubts of learners will be answered by teachers and serve as a guidance for the independent learning (Choe \& Seong, 2016). Teachers play the role as facilitator and provides help when needed. The learners have control over their learning progress while having maximum freedom of learning based on their competency, speed, and their cognitive level (Du, 2018; Yavuz \& Ozdemir, 2019).

In Malaysian context, the Ministry of Education has introduced the Malaysian Education Blueprint 2013-2025. There are eleven shifts in the blueprint. The 7th shift of the blueprint focuses on the significance of information and communication technology (ICT). The government aimed to increase the use of ICT for distance and independent learning to develop high-quality teaching irrespective of location or students' competency level. This is in-line with the concept of blended learning, where flipped classroom or flipped learning is an element of blended learning (Zainuddin \& Halili, 2016). The blended learning approach is anticipated to increase the quality of the teaching and learning in Malaysia. There are quite a number of studies that have been done in Malaysia on the topic of flipped learning (Rahman et al., 2019). In fulfilling the requirements of the globalization era, Massive Online Open Courses (MOOCs), blended learning and digital technology have been unified with the Malaysian higher education system (Rahman et al., 2019). The flipped learning approach is starting to gain some position in the Malaysian education domain.

\section{Factors Affecting the Implementation of Flipped Classroom Approach}

The inadequate autonomous learning ability of learners is one of the factors influencing the implementation of flipped classroom. Flipped classroom is completed by the practices of independent learning capacity of students. Teachers provide learners with plenty of reading resources or materials in advance. As mentioned by Sakulprasertsri (2017), the learners in a flipped classroom setting are required to explore the content of learning in greater depth by themselves. According to Du (2018), the learners were also required to search for additional materials on the Internet and complete the assigned exercises before the next lesson. In the context of tertiary level education, learners are often required to take the autonomy in their learning by searching for the materials by themselves. Hence, the learners might have problems in adapting the flipped learning if they are not autonomous learners. The distraction on the Internet may interfere with the learning process. Furthermore, autonomous learning required the learners to have high self- discipline. Furthermore, learners found it challenging to take responsibility for their own learning at home due to many distractions which may cause them to lose concentration (Du 2018; Nguyen et al. 2018;). Flipped classroom approach needs the cooperation between the educators and learners for the success of the method. However, learners' unwillingness to experience online learning might cause the approach ineffective in producing the intended outcomes (Yavuz \& Ozdemir, 2019).

Another factor that affects the flipped classroom approach is the limitations of infrastructures especially the ICT resources. According to the research done by Nguyen et al. (2018), the common challenges concerned the flipped classroom is the limitations of infrastructures such as ICT appliances and strong internet connection. As flipped classroom approach normally involved videos and relies heavily on electronic materials, the ICT infrastructures are essential to ensure the approach a success. Learners need to have computer, laptop, speakers, and strong internet connection. Some learners might not have the ability to own a computer or laptop, and limited internet connection could face problem in viewing the online lessons 
(Nguyen et al., 2018; Yavuz \& Ozdemir, 2019). This is further backed up by a research carried out by Ansori \& Nafi (2018), which stated that flipped classroom relied primarily on the internet access. The flipped classroom could not be carried out when the internet access was interrupted.

\section{Methodology}

This review is constructed on systematic analysis done on searched articles from databases which include Google Scholar and Educational Resources Information Centre (ERIC).

The searched articles are written in English language, published between years 2016 and 2020 (research carried out over the past five years). There were a few terms used to search for the past related research articles in the keywords fields of the above databases. Later, the related terms were checked in each database and the searches were polished and only related articles were being selected based on the research areas, document types, language used, and publication years. The title and abstract for these articles were screened through as well.

Hence, after the screening of past research articles based on the criteria stated above, 18 articles were being chosen. After reading the articles, a systematic review is conducted based on the five phases proposed by Khan (2003). The results of analysis will be tabulated in the results and discussion part. Figure 1 shows the five phases of Systematic Literature Review by Khan (2003).

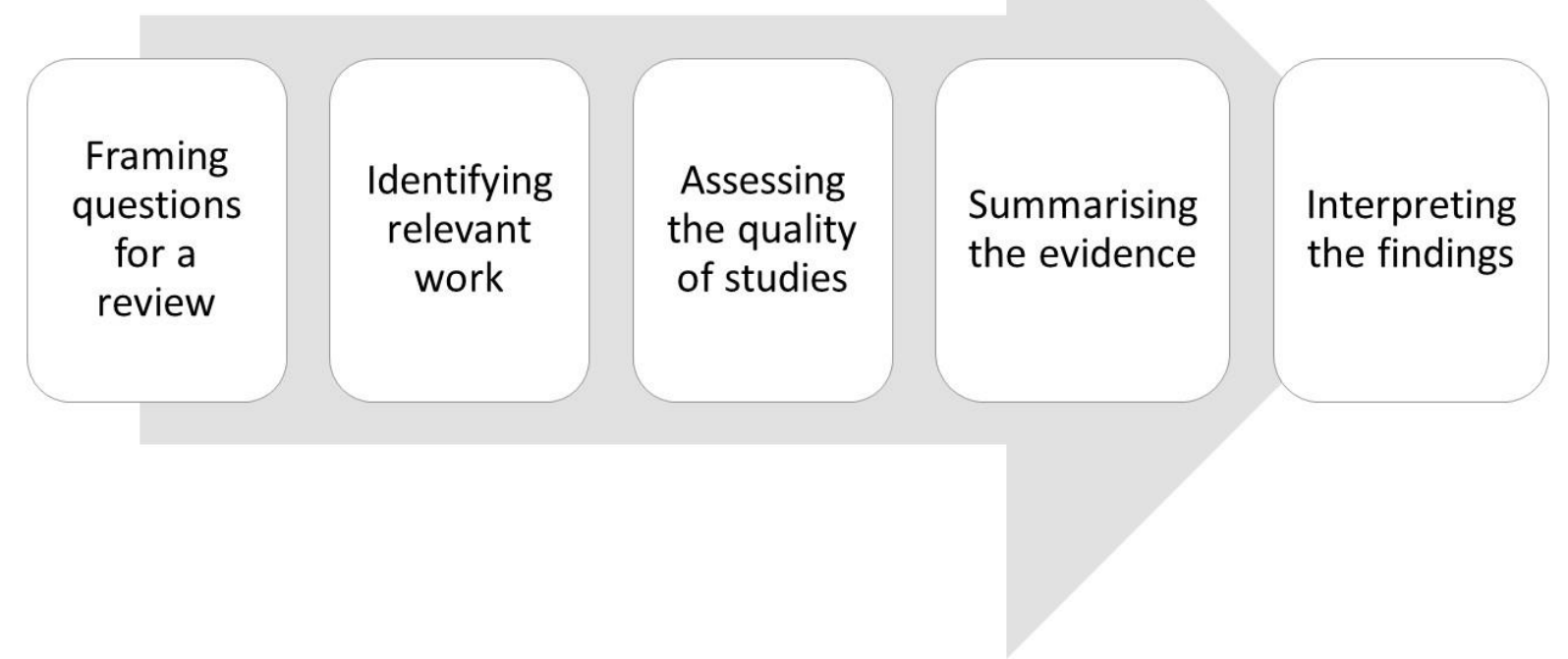

Figure 1. Five phases of Systematic Literature Review proposed by Khan (2003).

\section{Phase 1: Framing Questions for a View}

Many educators are aware of the traditional teaching approach or the teacher-centred learning often contributed to the passiveness in the classroom. The learners become passive and not taking initiative in learning. Hence, flipped classroom becomes a choice for teachers to promote active learning in the classroom. So, this review aims to analyse the English language teachers' and ESL or EFL learners' perception on the implementation of Flipped Classroom, published from the years 2016 to 2020. The research questions are: a) What are the English language teachers' perceptions on the implementation of flipped classroom? b) What are the learners' perceptions on the implementation of flipped classroom? 


\section{Phase 2: Identifying Relevant Work}

The next phase in a systematic literature review is discovering relevant articles. There were two steps in this phase. First, collect all the related articles on past studies. Next, choose the appropriate articles based on the inclusion and exclusion criteria proposed. In this review, books chapters are not being selected. The search on the databases was restricted to the fulltext articles and journal articles. The two databases used in this review were Google Scholar and Educational Resources Information Centre (ERIC). The articles selected were published between 2016 to 2020. The keywords used to search for the relevant studies were teachers'/ educators' perceptions on flipped ESL/EFL classroom, and learners' perceptions on flipped ESL/EFL classroom.

\section{Phase 3: Assessing the Quality of Studies}

The third phase in performing a systematic literature review is assessing the quality of studies. The inclusion criteria were specified to pinpoint the articles that will be included or excluded for this review. Only the articles that match the inclusion criteria of the study were carefully chosen. This is important to avoid inclusion of irrelevant studies. Therefore, only 18 out of 87 articles have met the inclusion criteria selected.

- Implementation of Flipped Classroom approach

- $\quad$ Teachers' and learners' perceptions on Flipped Classroom

- $\quad$ Teaching and learning that involved English Language (ESL and EFL)

- $\quad$ Participants or respondents from various level of education

- Journal and articles on educational fields

- $\quad$ Articles written in English language

- $\quad$ Published between year 2016 to 2020

There were seven inclusion criteria and six exclusion criteria decided for this systematic literature review. The articles that matched all the inclusion criteria were selected, while those matched the exclusion criteria, which might interfere the study were omitted. The rationale behind this is to ensure that only relevant journal articles to be chosen as a part of this systematic review.

\section{Phase 4: Summarising the Evidences}

The databases used in searching for past studies articles are Google Scholar and ERIC. The search using the keywords "teachers' perceptions towards Flipped Classroom in ESL" and "students' perceptions towards Flipped Classroom in ESL" resulted in a total of 134 articles published between year 2016 until 2020 in Google Scholar and ERIC databases. After reviewing the articles titles, abstract, keywords, results, and conclusion, 87 articles were selected. After refining the articles, excluded the articles that did not match the inclusion criteria, only 18 articles were selected to be included in this review.

\section{Phase 5: Interpreting the Findings}

The fifth phase is interpreting the findings by analysing the content. A total of 18 articles that matched the proposed inclusion criteria were selected to be reviewed in this review, mainly about the teachers' and the learners' perception on the implementation of Flipped Classroom in the ESL or EFL classroom. The participants or respondents in the selected articles were from any level of education. Table 1 revealed the methodology of the 18 selected articles, published from the year 2016 to 2020 . 


\begin{tabular}{cc}
\hline Methodology & Number of articles \\
\hline Qualitative & 4 \\
\hline Quantitative & 1 \\
\hline Mixed method & 13 \\
\hline Total & $\mathbf{1 8}$
\end{tabular}

Table 1. The methodology in the previous studies

\section{Result}

\section{What are the English language teachers' perceptions on the implementation of flipped classroom?}

The perceptions of English language teachers on the implementation of Flipped Classroom were being studied in the past research. Most of the results shown in the articles were showing positive feedbacks. Teachers were positive on the implementation of the Flipped Classroom approach to create a more active learning environment. The discussion of each authors is tabulated in Table 2.

\begin{tabular}{|c|c|c|}
\hline No. & Authors & Discussions \\
\hline 1. & $\begin{array}{r}\text { Dweikat, K. A. J. \& } \\
\text { Raba, A. A. A. } \\
\text { (2019) }\end{array}$ & $\begin{array}{l}\text { - Total degree of teachers' responses was (3.85) which suggested a high level of perceptions. } \\
\text { - The first group was in favour of using the FL model with mature learners after providing the } \\
\text { required infrastructure. } \\
\text { - The second group was not in favour of using the FL model because it might add more } \\
\text { responsibilities and tasks to the overloaded teachers, and it might distract learners as well. }\end{array}$ \\
\hline 2. & $\begin{array}{r}\text { Ansori, M. \& Nafi, } \\
\text { N. N. (2018). }\end{array}$ & $\begin{array}{l}\text { - The teachers show positive reactions to the flipped classroom methodology. } \\
\text { - The implementation facilitated active learning, developed collaboration and teamwork among } \\
\text { learners, encouraged autonomous learning, and increased classroom communication. } \\
\text { - The challenges included the needs of supporting facilities, technical and technological problems, } \\
\text { and the challenges of producing flipped learning materials by the teachers. }\end{array}$ \\
\hline 3. & $\begin{array}{l}\text { Gough, E. et al. } \\
\text { (2017) }\end{array}$ & $\begin{array}{l}\text { - The rewards of the flipped classroom are it is beneficial for absent learners, increased active } \\
\text { learning, increased interaction between teacher and students, better time management for } \\
\text { other related learning activities, and struggling learners were able re-watch recorded lessons. } \\
\text { - Teachers agreed that availability to technology outside of school could be an issue for some } \\
\text { learners in a flipped classroom. }\end{array}$ \\
\hline 4. & $\begin{array}{l}\text { Yang, R. C. C. \& } \\
\text { Chen, Y. Y. (2020) }\end{array}$ & $\begin{array}{l}\text { - Flipped classroom helped to increase the teaching and learning effectiveness within the } \\
\text { restricted class hour. } \\
\text { - Learners were more responsible for their learning and enhanced their independent learning } \\
\text { skills. } \\
\text { - Parents' support and cooperation among colleagues are important. }\end{array}$ \\
\hline 5. & Yang, R. C. C. (2017) & $\begin{array}{l}\text { - Teachers considered that the flipped classroom was creative and may be useful for teaching } \\
\text { English grammar. } \\
\text { - Teachers believed that a flipped classroom may only be practical for more ambitious learners. } \\
\text { - However, the extra job capacity of finding or making pre-lesson videos was the main concern for } \\
\text { them. }\end{array}$ \\
\hline 6. & Mahalli et al. (2019) & $\begin{array}{l}\text { - Flipped classroom is implemented to give the chance to learners to prepare their lecture before } \\
\text { they attend classroom lessons. } \\
\text { - Station rotation model was chosen because it can assist learners to improve and discuss deeper } \\
\text { in group discussion led by the teacher about the material that the educators has shared. }\end{array}$ \\
\hline
\end{tabular}

Table 2. English language teachers' perception towards the implementation of Flipped Classroom

\section{What are the learners' perceptions on the implementation of flipped classroom?}

There were a lot of past studies focusing on the learners' perception on the implementation of Flipped Classroom Approach. Most of the learners have provided positive feedback about the implementation of Flipped Classroom. The discussion of each authors is tabulated in Table 3. 


\begin{tabular}{|c|c|c|}
\hline No. & Authors & Discussions \\
\hline 1. & $\begin{array}{r}\text { Doman, E. \& } \\
\text { Webb, M. (2017) }\end{array}$ & $\begin{array}{l}\text { - Results from surveys and interviews have shown positive impacts on the integration of } \\
\text { technology, social presence, and teacher orientation. } \\
\text { In the traditional approach classrooms, there were more challenges related with } \\
\text { technology and materials, and poor views toward integration of technology in assisting } \\
\text { learners' learning. }\end{array}$ \\
\hline 2. & $\begin{array}{r}\text { Haghighi, H. et al. } \\
\qquad(2018)\end{array}$ & $\begin{array}{l}\text { - The participants of the flipped group drastically surpassed their friends in the } \\
\text { conventional group in the post-test. } \\
\text { - The results have shown that most participants of the flipped group benefit from } \\
\text { learning English in a flipped learning environment. }\end{array}$ \\
\hline 3. & $\begin{array}{r}\text { Lee, G. \& Wallace, } \\
\text { A. (2017) }\end{array}$ & $\begin{array}{l}\text { - Findings have shown that the learners in the flipped classroom achieved higher regular } \\
\text { scores and were more engaged in the learning process than their peers in the } \\
\text { traditional classroom. } \\
\text { Most learners in this review seemed to appreciate learning English in a flipped learning } \\
\text { environment. }\end{array}$ \\
\hline 4. & $\begin{array}{r}\text { Zainuddin, Z. } \\
\text { (2017) }\end{array}$ & - Majority of the learners perceived the flipped classroom highly positive. \\
\hline 5. & $\begin{array}{r}\text { El-Esery, A. M. \& } \\
\text { Radwan, N. A. } \\
\text { (2017) }\end{array}$ & $\begin{array}{l}\text { - Computer-Assisted Language Learning programs in flipped classrooms enhanced the } \\
\text { learners' language learning approach and increase examination scores to a significant } \\
\text { level. }\end{array}$ \\
\hline 6. & $\begin{array}{r}\text { Ekmekci, E. } \\
(2017)\end{array}$ & $\begin{array}{l}\text { - The qualitative results show that the flipped classroom method is more enjoyable than } \\
\text { the traditional lecture-based lesson. } \\
\text { - The questionnaire shows learners enjoyed the flipped classroom. } \\
\text { - Study also shows the learner autonomy is supported. }\end{array}$ \\
\hline 7. & Nguyen, T (2018) & $\begin{array}{l}\text { - The findings indicated that learners developed their English skills and appreciated the } \\
\text { implementation of flipped approach in every class. }\end{array}$ \\
\hline 8. & $\begin{array}{r}\text { Fauzan, A. \& } \\
\text { Ngabut, M. N. } \\
(2018)\end{array}$ & $\begin{array}{l}\text { - } \quad \text { Flipped learning was effectively executed in the class. } \\
\text { - Learners agreed that shifting classroom environment can give new colours to the } \\
\text { learning activity. } \\
\text { - They could adjust their learning time at the time they felt comfortable. } \\
\text { In the classroom, the learners could explore the materials efficiently as they had } \\
\text { various learning methods such as individual work, group work, text analysis, and } \\
\text { project presentation. }\end{array}$ \\
\hline 9. & $\begin{array}{r}\text { Webb, M. \& } \\
\text { Doman, E (2016) }\end{array}$ & $\begin{array}{l}\text { - Flipped classroom helped learners to achieve their SLOs in grammar. } \\
\text { - Learners also feel more comfortable and assured in their English } \\
\text { grammar skills } \\
\text { - Learners took responsibility and were more entrusted in their own } \\
\text { learning. }\end{array}$ \\
\hline 10. & $\begin{array}{r}\text { Pudin, C. S. J. } \\
\text { (2017) }\end{array}$ & $\begin{array}{l}\text { - The analysis of the findings proved most of the learners were keen to learn grammar } \\
\text { through flipped classroom approach. }\end{array}$ \\
\hline 11. & $\begin{array}{r}\text { Alghasab, M. B. } \\
\qquad(2020)\end{array}$ & $\begin{array}{l}\text { - Learners have positive attitude towards the process of flipping the writing lessons. } \\
\text { - The flipped classroom provides a more effective learning environment, flexible paced } \\
\text { learning capable of improving learners' writing strategies and enhancement of } \\
\text { learners' motivation and interaction. }\end{array}$ \\
\hline 12. & $\begin{array}{r}\text { Farrah, M. \& } \\
\text { Qawasmeh, A. } \\
(2018)\end{array}$ & $\begin{array}{l}\text { - } \quad \text { Flipped classroom encourages more learner autonomy and self-supervision } \\
\text { - } \quad \text { Participants considered the flipped classroom exciting, inspiring, and participating. }\end{array}$ \\
\hline
\end{tabular}

Table 3. Learners' perception towards the implementation of Flipped Classroom

\section{Discussion}

Previous studies highlighted on teachers' and students' perception about the implementation of flipped classroom approach. The results of the studies show that majority of the teachers 
involved in the past studies have shown positive responses towards the implementation of flipped classroom. (Ansori \& Nafi, 2018; Dweikat \& Raba, 2019; Gough et al., 2018; Mahali, 2019; Yang, 2017; Yang \& Chen, 2020). The research findings have shown that flipped classroom provides benefits such as helping active learning, developing cooperation, enhancing autonomous learning, increasing classroom collaboration (Ansori \& Nafi, 2018), beneficial for absent learners, increased time for learners' active learning, increased interaction between teachers and students, benefitting the strugglers by re-watching recorded lessons (Gough et al., 2017). Furthermore, flipped classroom approach helped to increase the quality of teaching and learning within the restricted time, developing the learners' responsibility towards their learning while enriching their self-learning skills (Yang \& Chen, 2020). Furthermore, according to Mahalli et al. (2019), the findings have shown that teachers were positive with the flipped classroom approach as it provide chances to learners to prepare for their lecture before the lesson in the classroom and thus helping them in a deeper and meaningful group discussion in the classroom. However, teachers also considered flipped classroom is only useful for the highly motivated learners (Yang, 2017). In addition, they also felt that flipped classroom requires extra efforts and workload in preparing the materials, thus adding more tasks to the overloaded teachers (Dweikat \& Raba 2019; Yang 2017). Challenges such as facilities, technical problems and problems in creating flipped learning materials are the concerns as well (Ansori \& Nafi, 2018).

Majority of the learners have provided constructive feedback on the implementation of flipped classroom. The studies have shown that the learners agreed that flipped classroom brought positive impacts such as learners became more connected in the course and outpaced their friends in the traditional approach classroom (Haghighi et al., 2018; Lee \& Wallace, 2017; Zainuddin, 2017). Besides, the studies also proved that the flipped classroom is more enjoyable and fun than the traditional teaching approach, and they were keener to learn (Ekmekci, 2017; Haghighi et al., 2018; Lee \& Wallace, 2017; Pudin, 2017). Flipped classroom also helped the learners to be autonomous learners, improve the learning attitude and be more responsible in their learning process (Ekmekci, 2017; El-Esery \& Radwan, 2017; Farrah \& Qawasmeh, 2018; Webb \& Doman, 2016). Students also felt that the flipped classroom is motivating, exciting and engaging (Alghasab, 2020; Farrah \& Qawasmeh, 2018). Furthermore, students also stated that flipped classroom allowed them to learn at the time they felt convenient, and provided a more flexible learning speed (Alghasab, 2020; Fauzan \& Ngabut, 2018). However, beside the positive feedback gained in the previous studies, there were also challenges faced by the learners in the implementation of flipped classroom. According to Doman and Webb (2017), weaker attitudes towards the integration of technology in the learning process is one of the challenges faced by the learners in the flipped classroom approach. Overall, there were more positive feedback gained than the negative feedback. Thus, the implementation flipped classroom could yield promising outcomes.

\section{Conclusion}

In conclusion, the review on the 18 articles about the implementation of flipped classroom chosen showed positive feedback from the teachers' and students' perception. The teachers and learners perceived that the approach helped in the teaching and learning process as it provided more discussion opportunities and better time management. Flipped classroom is a modern teaching and learning approach which is not fully implemented yet in Malaysia. Despite the limitations in the implementation of flipped classroom, flipped classroom is still widely applied. To implement the flipped classroom approach, challenges should be 
overcome. Teachers and learners should be technology or ICT literate. Educators and learners need to upgrade themselves to be able to apply the flipped classroom in their teaching and learning process. Flipped classroom approach could build autonomous learning ability and it could help the learners and teachers. Based on the review, flipped learning is an effective approach and shall be implement by most of the learning institutions.

Hence, this systematic literature review is expected to provide guidance for future researchers who wish to conduct studies about the flipped classroom in English language teaching and learning. Besides, teachers or instructors who wish to change their teaching method from a traditional classroom to a flipped classroom should be able to gather information from this systematic literature review on the benefits of flipped classroom before starting the intended method.

\section{References}

Alghasab, M. B. (2020). Flipping the writing classroom: Focusing on the pedagogical benefits and EFL leaners' perceptions. English Language Teaching, 13(4), 28-40. doi:10.5539/elt.v13n4p28.

Ansori, M., \& Nafi, N. N. (2018). English teachers' perceived benefits and challenges of flipped classroom implementation. JEELS, 5(2), 211-226. doi:10.30762/jeels.v5i2.820.

Carhill-Poza, A. (2019). Defining flipped learning for English learners in an urban secondary school. Bilingual Research Journal, 42(1), 90-104. doi: 10.1080/15235882.2018.1561552.

Choe, E., \& Seong, M. H. (2016). A case study of the flipped classroom in a Korean university general English course. Journal of Pan-Pacific Association of Applied Linguistics, 20(2), 7193.

Doman, E., \& Webb, M. (2017). The flipped experience for Chinese university students studying English as a foreign language. TESOL Journal, 8(1), 102-141. doi: 10.1002/tesj.264.

Du, Y. (2018). Discussion on flipped classroom teaching mode in college English teaching. English Language Teaching, 11(11), 92-97. doi: 10.5539/elt.v11n11p92.

Dweikat, K. A. J., \& Raba, A. A. A. (2019). English as a foreign language (EFL) teachers' perceptions of flipped classroom model in Palestine. IUG Journal of Educational and Psychological Sciences, 27(3), 29-47.

Ekmekci, E. (2017). The flipped writing classroom in Turkish EFL context: A comparative study on a new model. Turkish Online Journal of Distance Education-TOJDE, 18(2), 151-167. doi: 10.17718/tojde.306566.

El-Esery, A. M., \& Radwan, N. A. (2017). Modeling CALL programs in EFL flipped classrooms to enhance achievement and language learning attitude. Journal of Research in Curriculum, Instruction and Educational Technology, 3(2), 115-125. doi: 10.21608/jrciet.2017.24466.

Farrah, M., \& Qawasmeh, A. 2018. English students' attitudes towards using flipped classrooms in language learning at Hebron University. Research in English Language Pedagogy, 6(2), 275-294. doi: 10.30486/RELP.2018.542708.

Fauzan, A., \& Ngabut, M. N. (2018). EFL students' perception on flipped learning in writing class. Journal on English as a Foreign Language, 8(2), 115-129. doi: 10.23971/jefl.v8i2.792.

Gough, E., DeJong, D., Grunmeyer, T., \& Baron, M. (2017). K-12 teacher perceptions regarding the flipped classroom model for teaching and learning. Journal of Educational Technology Systems 45(3), 390-423. doi: 10.1177/0047239516658444. 
Haghighi, H., Jafarigohar, M., Khoshsima, H., \& Vahdany, F. (2018). Impact of flipped classroom on EFL learners' appropriate use of refusal: achievement, participation, perception. Computer Assisted Language Learning, 32(3), 261-293. doi: 10.1080/09588221.2018.1504083.

Halili, S. H., \& Zainuddin, Z. (2015). Flipping the classroom: what we know and what we don't. The Online Journal of Distance Education and e-learning, 3(1), 28-35.

Han, Y. J. (2015). Successfully flipping the ESL classroom for learner autonomy. NYS TESOL Journal, 2(1), 98-109.

Khan, K. S., Kunz, R., Kleijnen, J., \& Antes, G. (2003). Five steps to conducting a systematic review. Journal of the Royal Society of Medicine, 96(3), 118-121. doi: 10.1258/jrsm.96.3.118.

Lee, G., \& Wallace, A. (2017). Flipped learning in the English as a foreign language classroom: Outcomes and perceptions. TESOL Quarterly, 52(1), 62-84. doi: 10.1002/tesq.372.

Mahalli, N. J., Mujiyanto, J., \& Yuliasri, I. (2019). The implementation of station rotation and flipped classroom models of blended learning in EFL learning. English Language Teaching, 12(12), 23-29. doi: 10.5539/elt.v12n12p23.

Malaysia Education Blueprint. (2015). Malaysia Education Blueprint 2013-2025 (Higher Education). Kementerian Pendidikan Malaysia.

Nguyen, H. A. V., Tan, C. K., \& Lee, K. W. (2018). Students' perceived challenges of attending a flipped EFL classroom in Vietnam. Theory and Practice in Language Studies, 8(11), 15041510. doi: 10.17507/tpls.0811.16.

Nguyen, T. (2018). Implementation of English flipped classrooms: Students' perceptions and teacher's reflection. International Journal of Research Studies in Language Learning, 7(3), 87-108. doi: 10.5861/IJRSLL.2017.1876.

Pudin, C. S. J. (2017). Exploring a flipped learning approach in teaching grammar for ESL students. IJELTAL Indonesian Journal of English Language Teaching and Applied Linguistics, 2(1), 51-64. doi: 10.21093/ijeltal.v2i1.47.

Rahman, S. F., Yunus, M. M., \& Hashim, H. (2019). An overview of flipped learning studies in Malaysia. Arab World English Journal, 10(4), 194-203. doi: 10.24093/awej/vol10no4.15.

Sakulprasertsri, K. (2017). Flipped learning approach: Engaging 21st century learners in English classrooms. LEARN Journal: Language Education and Acquisition Research Network Journal, 10(2), 132-143.

Webb, M., \& Doman, E. (2016). Does the flipped classroom lead to increased gains on learning outcomes in ESL/ EFL contexts? The CATESOL Journal, 28(1), 39-67.

Yavuz, F., \& Ozdemir, S. (2019). Flipped classroom approach in EFL context: Some associated factor. World Journal on Educational Technology: Current Issues, 11(4), 238-244. doi: 10.18844/wjet.v11i4.4296.

Yang, R. C. C., \& Chen, Y. Y. (2020). Implementing the flipped classroom approach in primary English classrooms in China. Education and Information Technologies, 25(2), 1217-1235. doi: 10.1007/s10639-019-10012-6.

Yang, R. C. C. (2017). An investigation of the use of the 'flipped classroom' pedagogy in secondary English language classrooms. Journal of Information Technology Education: Innovations in Practice, 16, 1-20. doi: 10.28945/3635.

Zainuddin, Z., \& Halili, S. H. (2016). Flipped classroom research and trends from different fields of study. International Review of Research in Open and Distributed Learning, 17(3), 313340. doi: 10.19173/irrodl.v17i3.2274. 
INTERNATIONAL JOURNAL OF ACADEMIC RESEARCH IN BUSINESS AND SOCIAL SCIENCES

Vol. 11, No. 3, 2021, E-ISSN: 2222-6990 @ 2021 HRMARS

Zainuddin, Z. (2017). First-year college students' experiences in the EFL flipped classroom: A case study in Indonesia. International Journal of Instruction, 10(1), 133-150. doi: 10.12973/iji.2017.1019a. 